\title{
Human-impacted mangroves in Gazi (Kenya): predicting future vegetation based on retrospective remote sensing, social surveys, and tree distribution
}

\author{
F. Dahdouh-Guebas ${ }^{1,2, *}$, I. Van Pottelbergh ${ }^{1}$, J. G. Kairo ${ }^{3,1}$, S. Cannicci ${ }^{4}$, N. Koedam ${ }^{1}$ \\ ${ }^{1}$ Biocomplexity Research Team, Laboratory of General Botany and Nature Management, Mangrove Management Group, \\ Vrije Universiteit Brussel, Pleinlaan 2, 1050 Brussels, Belgium \\ ${ }^{2}$ Uitgegeven met steun van de Universitaire Stichting van België, Egmontstraat 11, 1000 Brussels, Belgium \\ ${ }^{3}$ Kenya Marine and Fisheries Research Institute, PO Box 81651, Mombasa, Kenya \\ ${ }^{4}$ Dipartimento di Biologia Animale e Genetica 'Leo Pardi', Università degli Studi di Firenze, Via Romana 17, 50125 Firenze, Italy
}

\begin{abstract}
Gazi Bay, Kenya, covers an area of $18 \mathrm{~km}^{2}$, and its mangroves are degraded. We present a quantitative and qualitative evaluation of the degradation of vegetation structure and dynamics of mangrove communities over a period of $25 \mathrm{yr}$, using aerial photography in a geographical information system (GIS), combined with ground-truth data for different vegetation layers, and with faunal and environmental factors. Retrospective analysis and understanding of current practices were aided by interviews with Gazi village elders and by field observations of mangrove tree stumps. GIS-based vegetation maps were combined with data obtained using the point-centred quarter method (PCQM), an accuracy analysis was performed, and forestry parameters were derived from the resultant PCQM data. In addition to general human-induced degradation of vegetation structure and floristic composition of the seaward mangrove zone, a particular sandy beach is expanding at the expense of mangrove, whereas the back mangrove zone has undergone minor changes. Aerial photographs of 1992 and current field data show an apparent zonation of 6 different monospecific or mixed mangrove communities, with a high importance of Rhizophora mucronata in each community and each vegetation layer. Retrospective vegetation structure was combined with correspondence analyses on the PCQM data derived for adult, young and juvenile trees in order to make predictions. Present dynamics initiated by anthropogenic degradation of mangroves continues, even though human impact has diminished. We predict that under a 'no impact scenario', the sandy ridge will continue to expand, that this will speed up under a 'mangrove cutting scenario', and that a scenario altering the complex topography will lead to a major re-organisation of the mangrove and terrestrial vegetation structure.
\end{abstract}

KEY WORDS: Mangroves · Dynamics · Aerial photography $\cdot$ Macrobenthos $\cdot$ Multivariate analysis · Forecasting $\cdot$ Interviews $\cdot$ Kenya

\section{INTRODUCTION}

Understanding vegetation dynamics is important for conservation, restoration and sustainable exploitation purposes. Mangrove formations, which are often undervalued and destroyed as a result of various forms of human activity (e.g. Farnsworth \& Ellison 1997), display major structural changes within a short time- frame (Dahdouh-Guebas et al. 2000b). The driving forces of these dynamics are not known. Therefore, and because mangroves are probably fundamentally different in various ecological settings, an insight into the processes involved in the dynamic shifts in mangrove vegetation structure is required. There is a lack of data on the undisturbed state of mangroves (apart from observations supplied by local inhabitants). An 
investigation of the anthropogenic or endogenic/autoecological factors in mangrove dynamics is necessary. In Kenya, where the adverse effect of predation on the initial regeneration of mangroves has been documented (Dahdouh-Guebas et al. 1997, 1998), the experimental design of reforestation projects might benefit from this type of fundamental research. Furthermore, it serves as a basis for deciding whether or not human interference in the form of management or restoration is appropriate. Providing data on the potential of a mangrove stand to successfully renew and rejuvenate can assist predictions (Dahdouh-Guebas 2002).

The first objective of this study was to make a quantitative and qualitative evaluation of the past and present vegetation structure dynamics in a mangrove forest in Gazi Bay, Kenya, emphasizing and confirming the anthropogenic degradation that has taken place in the past. The study was aimed at interpreting past and present mangrove vegetation structure using aerial photography analysis and field studies of the adult vegetation. A second objective was to extrapolate the interpretation to future dynamics through fieldwork on young and juvenile vegetation layers. The study combines remote sensing data and ordination analysis to make predictions based on vegetation history.
Retrospective analysis, understanding of current practices and forecasting were also aided by interviews with Gazi village elders and by visual observations of mangrove tree stumps in the field.

\section{MATERIALS AND METHODS}

Study area. In Gazi Bay $\left(4^{\circ} 26^{\prime} \mathrm{S}, 39^{\circ} 30^{\prime} \mathrm{E}\right)$, located about $45 \mathrm{~km}$ south of Mombasa, more than $6.15 \mathrm{~km}^{2}$ of mangrove forest has developed (Fig. 1), much of which is subject to severe human impact (e.g. Beeckman et al. 1989, Gallin et al. 1989, Vanhove et al. 1992, Kairo 1995a, Schrijvers et al. 1995, Fondo \& Martens 1998, Aloo 2000, Dahdouh-Guebas et al. 2000a, Hoorweg et al. 2000, Abuodha \& Kairo 2001, Kairo et al. 2001). This study concentrates on a mangrove stretch adjacent to the village of Gazi (see Fig. 3), one of the most affected areas. Kidogoweni and Mkurumuji, 2 seasonal rivers, provide most of the overland freshwater input into the bay, but tidal influences (spring tidal amplitude is about 3.5 to $4 \mathrm{~m}$ ) are more important. All 10 EastAfrican mangrove species, i.e. Avicennia marina (Forsk.) Vierh., Bruguiera gymnorrhiza (L.) Lam., Ceriops tagal (Perr.) C.B. Robinson, Heritiera littoralis Dryand., Lumnitzera racemosa Willd., Pemphis acidula Forst., Rhizo- (a)

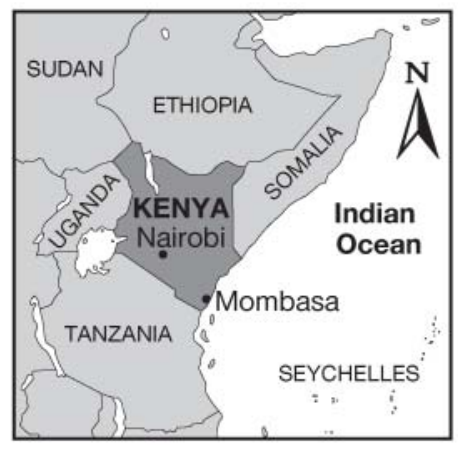

(c)

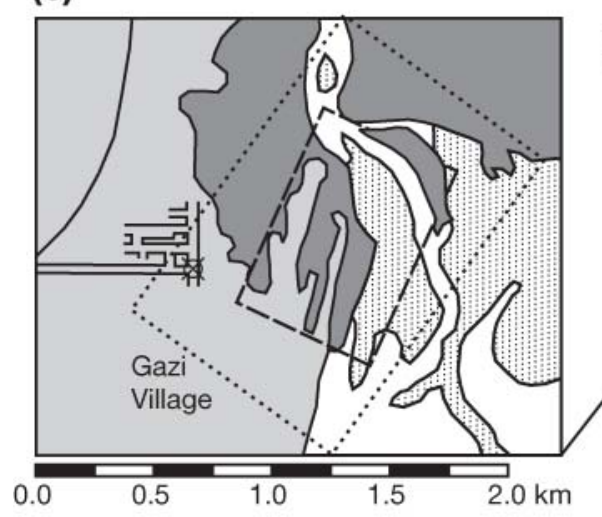

(b)

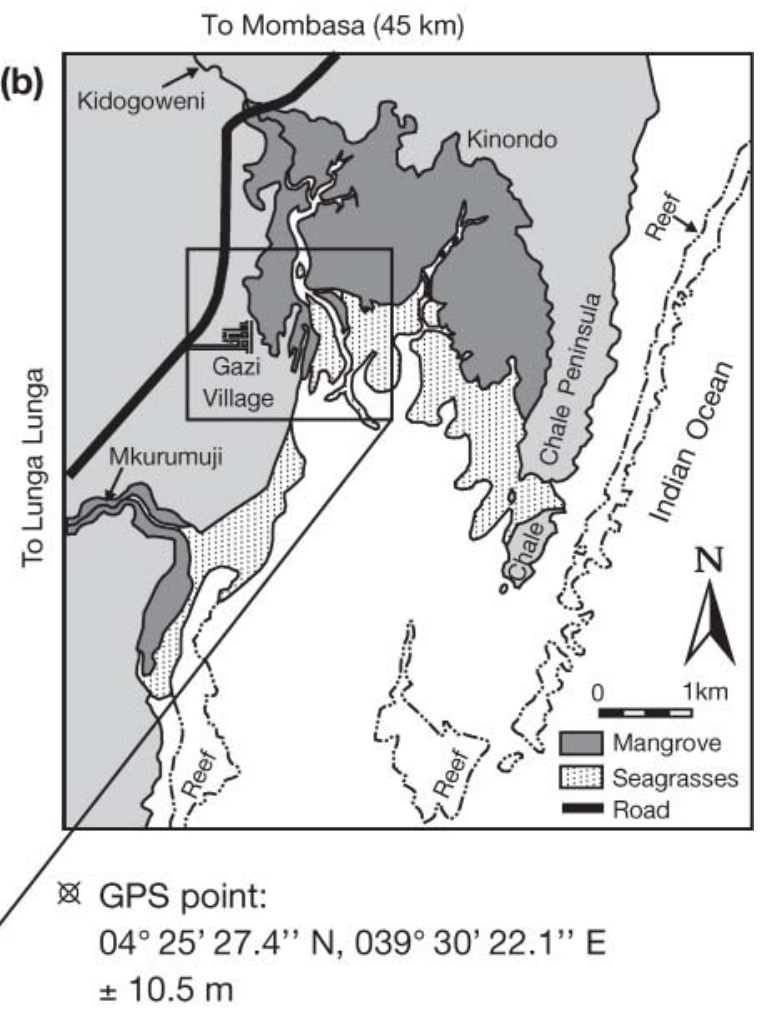

Fig. 1. (a) Kenya. (b) Gazi Bay, showing areas of mangroves, seagrasses and coral reef. (c) Location of study site in Gazi Bay and approximate extent of aerial photograph of 1972 (dashed rectangle) and that of 1992 (dotted rectangle) (see Fig. 3). (For detailed map of coast see Dahdouh-Guebas et al. 2002b) 
phora mucronata Lam., Sonneratia alba Sm., Xylocarpus granatum Koen. and X. moluccensis (Lamk.) Roem. (nomenclature according to Tomlinson 1986, Duke \& Jackes 1987, Duke 1991), occur along the Kenyan coast, and their presence has been reported in Gazi Bay. $X$. moluccensis was, however, not observed during the course of this study.

Climatic data are available for Mombasa (Fig. 2), and the data list an average annual rainfall of $1136.47 \mathrm{~mm}$ (period 1890-2001) and an average annual temperature of $26.15^{\circ} \mathrm{C}$ (period $1931-2001$ ). The rainfall trend during the study period (1997-1999) was not different from the average, except for the period October 1997 to February 1998, which included an El Niño event and had considerably more rainfall than the usual pattern (October 826 mm, November 317 mm, December 285 $\mathrm{mm}$, January $213 \mathrm{~mm}$, February $50 \mathrm{~mm}$ ). Apart from an early study (Jeathold \& Smidt 1976), no detailed climatic data were available for the specific study area. However, the rainfall pattern in Gazi Bay is the same as in Mombasa (Teathold \& Smidt 1976) with an annual average that may be slightly higher in Gazi due to the direction of the trade-winds (south-east and northeast), the differences in relief, and hence a less than perfect east-west gradient in the rainfall (Hoorweg et al. 2000).

Photogrammetry. We obtained 2 aerial photographs, one for 1972, the other for 1992, at scales of 1:7500 and

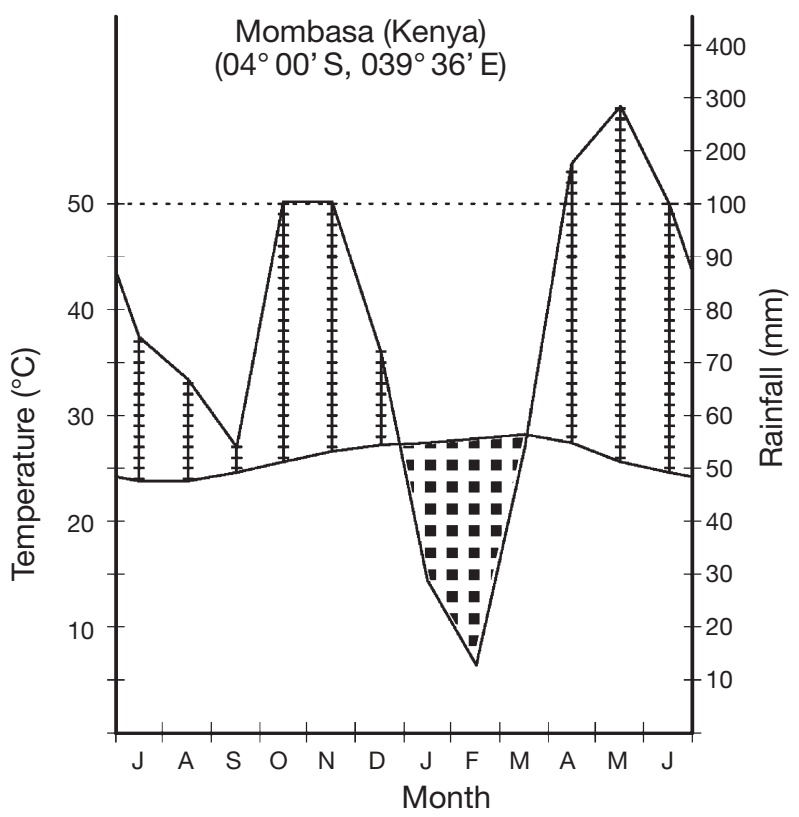

Fig. 2. Climate diagram for Mombasa. Monthly rainfall data (upper continuous line) are from Lieth et al. (1999) for period 1890-1985 complemented with data from Meteorological Department in Mombasa for period 1986-2001. Monthly temperature data (lower continuous line) are from Lieth et al. (1999) for period 1931-1990 complemented with data from Meteorological Department in Mombasa for period 1991-2001
1:12 500 respectively, from the Kenyan Survey Department. These were photographically enlarged (Kodak 5052 TMX) using a $50 \mathrm{~mm}$ macro lens, then scanned at 300 dots per inch (dpi), and digitised in a geographic information system (GIS), using MapInfo software on a Macintosh computer platform to outline polygon vectors corresponding to mangrove zones. In this study the term 'zonation' is defined as 'banding of vegetation types with a certain floristic composition, usually strongly dominated by a single species'. The identification of vegetation assemblages was based on the image attributes of tonality, texture and structure (Dahdouh-Guebas et al. 2001) as successfully applied to the identification of mangroves in the framework of mangrove vegetation dynamics research in the past (Dahdouh-Guebas et al. 2000b, Verheyden et al. 2002). The aerial photographs were not co-registered and overlayed for a number of reasons. First, there was a lack of reliable ground control-points common to both aerial photographs to enable effective co-registering of both photographs. Second, an overlay of the 2 photographs, with their many vegetation assemblages in a small area, resulted in an excessive amount of vegetation classes that obscured interpretation (DahdouhGuebas et al. 2000b); it was thus far more appropriate to be able to compare and interpret the original vegetation maps from the 2 photographs separately. Third, the overlay of the ground-truth transects on the most recent photograph was more accurate using visual cues such as trees than using the Global Positioning System (GPS) (Dahdouh-Guebas et al. 2000b, Dahdouh-Guebas 2002). However, in order to extract some surface data with respect to the vegetation assemblages, 5 GPS points with an average accuracy of $10.5 \mathrm{~m}$ were relied upon to georeference the photographs. The 1992 photograph was ground-truthed in 1997 as a result of the delayed availability of the photographs, and for practical and logistic considerations. Incorporation of this time-gap of 5 yr was based on the absence of major visual differences in areal extent or floristic composition of vegetation assemblages in the field (pers. obs. by F.D.G. \& J.G.K. on a semestrial basis since 1992), and the absence of substantial differences from the zonation in 1993 (cf. Dahdouh-Guebas et al. $2002 \mathrm{~b}$, in press). Nevertheless, the results of this study were interpreted with careful consideration of this time gap. Ground-truthing consisted of visits to all the mangrove assemblages outlined in the digitisation of the photograph as well as land-creek transects through the mangrove vegetation.

Field survey. The field survey served to determine the vegetation structure in different layers and to investigate a selection of environmental factors in the study area (see below). During the a first field survey in July to August 1997 (wet season), 6 transects (5 par- 
allel transects and 1 orthogonal) were surveyed in the most anthropogenically degraded part of our study site (Fig. 3). The orthogonal transect was covered in order to corroborate a zonation pattern observed on the image and in the other transects, but it did not provide additional information and is therefore not shown in the relevant figures. Its vegetation data were however used in the multivariate analyses (see later subsection). Sampling at $10 \mathrm{~m}$ intervals was undertaken using the point-centred quarter method, PCQM (Cottam \& Cur- tis 1956) as described by Cintrón \& Schaeffer Novelli (1984). The individual tree closest to the sample point was identified and recorded in each of 4 quadrants, and its height and diameter, $d_{130}(130 \mathrm{~cm}$ height sensu Brokaw \& Thompson [2000], formerly referred to as $\mathrm{DBH}$, the diameter at breast height) were measured. The stem diameter of mangrove species with aerial roots at $130 \mathrm{~cm}$ height was measured $30 \mathrm{~cm}$ above the highest roots. Other anomalies to the application of the PCQM (e.g. forking stems) were dealt with as

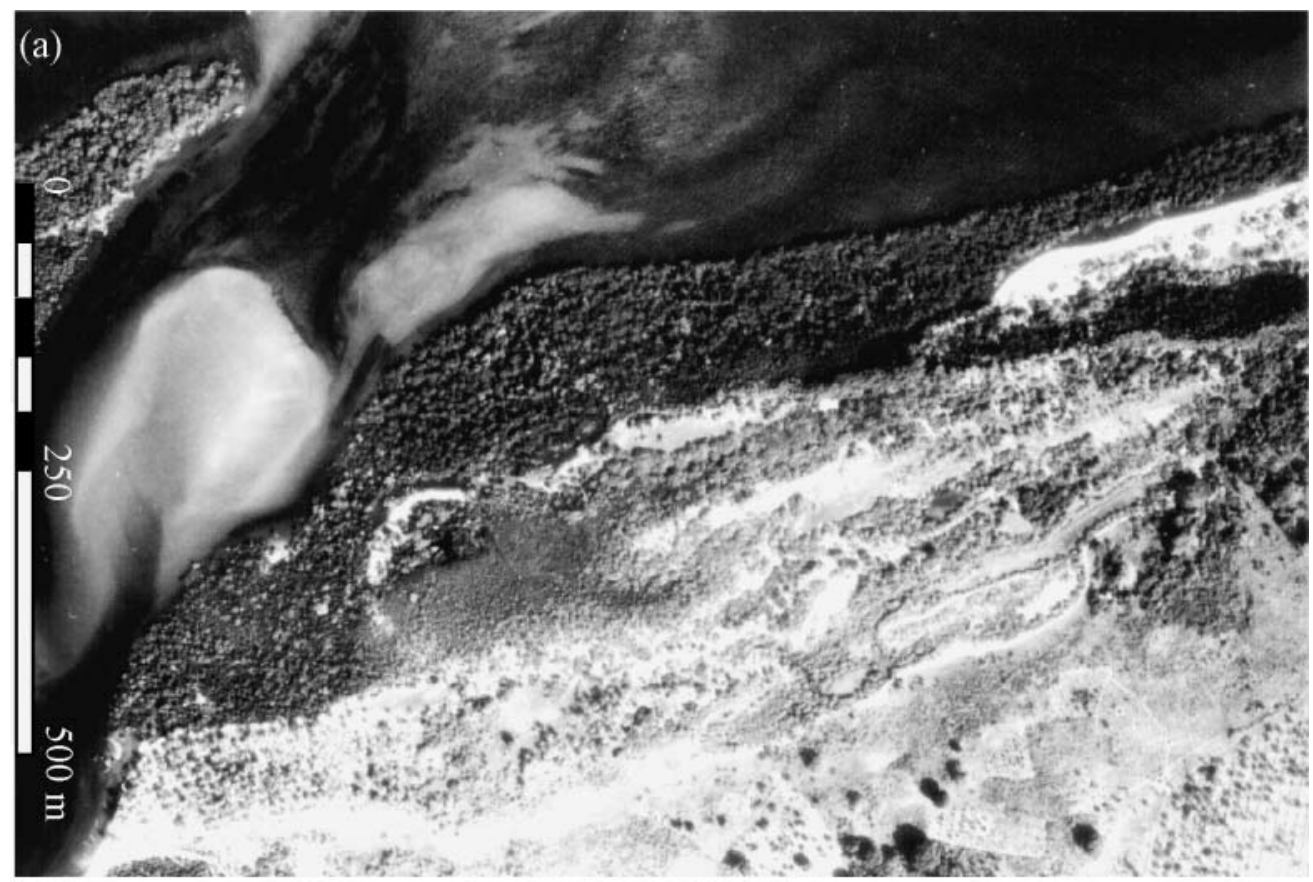

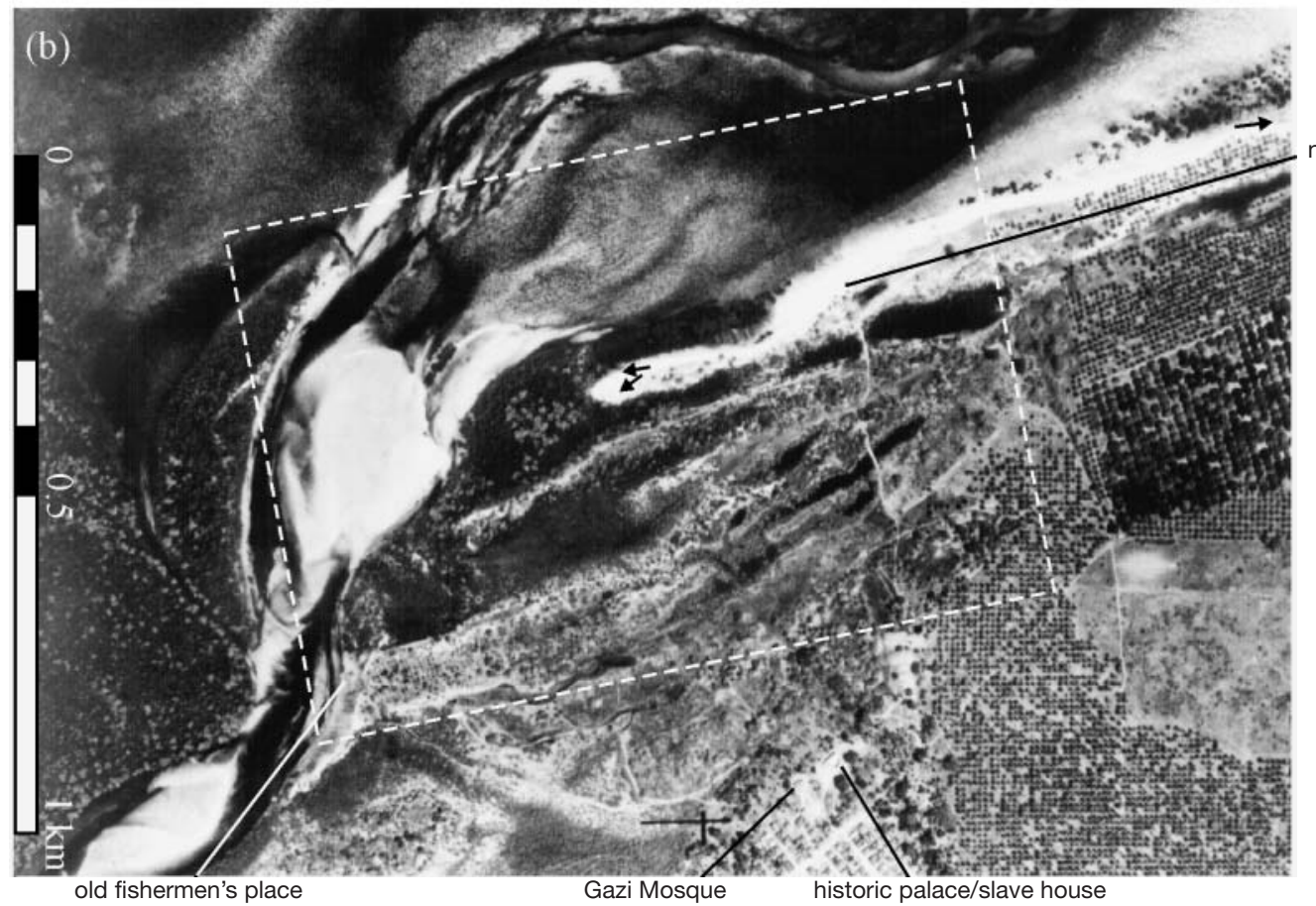

new fishermen's place

Fig. 3. Aerial photographs of study site in (a) 1972 and (b) 1992. The latter shows important local features and approximate extent of 1972 photograph (dashed rectangle). In (b), the 2 arrows pointing left (centre of photo) and that pointing right (upper right) indicate approximate locations of photographs in

Fig. 5a,b,c respectively 
described by Cintrón \& Schaeffer Novelli (1984). The total vegetation cover was estimated in percentages in the $5 \mathrm{~m} \times 5 \mathrm{~m}$ quadrat nearest to the sampling point (the sample point thus formed the common corner point of the 4 quadrats located in the 4 quadrants). Each transect was sampled for vegetation description within $3 \mathrm{~d}$ to locate and describe mangrove juveniles (propagules or seeds up to the stage of sapling), young mangrove trees (trees smaller than $1.3 \mathrm{~m}$ or with a $d_{130}<2.5 \mathrm{~cm}$, but which had reached the sapling stage, a plant with more than 6 leaves), and adult mangrove trees. These 3 stages represent different phases critical to the survival of mangroves in this area: (1) mangrove juveniles that are subject to potential stressful conditions in the pre- and post-dispersal development of the plant, particularly propagule predation, which is known to be a significant constraint in Kenya (Dahdouh-Guebas et al. 1997, 1998); (2) young mangrove trees, which have survived predation disturbance but are still vulnerable to other disturbance and stress factors such as drought, water movement, erosion, sedimentation, etc.i (3) adult mangrove trees, plants that are well established and are likely to survive, provided no devastating natural or human impacts occur. Only the adult vegetation could be used as a link to the aerial photographs as it represented the remotely sensed canopy. The diameter of young mangrove trees and juveniles was not measured as they were too small to be relevant in this study.

A second field study was organised in March 1999 (dry season) in order to detect possible seasonal changes in the distribution and abundance of mangrove juveniles. We were unable to sample a representative dry season in 1998 due to the El-Niño event at the transition of 1997 to 1998 (mentioned earlier). Along 2 additional transects (Transects A and B), crossing the complete vegetation belt (including terrestrial vegetation) from the village to the creek, mangrove species were recorded to confirm the land-sea zonation and to detect any zone not visible from the aerial photograph (particularly species encroaching on the terrestrial vegetation). Environmental factors such as salinity (determined with an Atago refractometer with a precision of $1 \%$, over a scale from 0 to $100 \%$ ), light intensity (determined with a Lutron lux-meter with a precision of $4 \%$ of the resolution scale, which ranged from 1 to 100 lux), herbivorous crab abundance and snail abundance (by burrow and individual counts in $1 \mathrm{~m}^{2}$ quadrats in each of the 4 PCQM quadrants) were also recorded. These 4 environmental factors were selected in particular because they have been reported by univariate studies to play a significant role in the establishment of vegetation structure (Smith 1987, 1992, Dahdouh-Guebas et al. 1998, Matthijs et al. 1999).

Visual observations and interviews with local people were carried out whenever possible over the whole duration of the fieldwork, in order to complement the retrospective data. Apart from historic aerial photographs and mangrove tree stumps, village elders are the only source of information on the past extent and composition of mangroves. The complementation of basic scientific data with such sociological information is an added value for research (e.g. Cormier-Salem 1999). Free and open-ended interviews on the history of the mangrove vegetation in Gazi (emphasising changes in area and species composition) were carried out in Kiswahili at 11 different families in the village. At the time of the survey there were a total of 119 houses in Gazi (Vandeput 1999), and on average 1 family occupies one house (pers. obs. by F.D.G. \& I.V.P.). The age of the people interviewed was $>40 \mathrm{yr}$, a period extending retrospectively well beyond the date of the first aerial photograph (1972).

Data analysis. Vegetation maps of 1972 and 1992 were drawn up and the field transects were traced onto the most recent aerial photograph (1992) using visual cues. The data originating from the PCQM, usually used to calculate forest structural parameters only, were here transformed into visual data that allow their use in a GIS. PCQM transect data for adult, young and juvenile mangrove species were visualised in separate GIS layers as squares representing the 4 quadrants superimposed on the vegetation map of 1992. The ratio of PCQM sample-points occupied by the adult mangrove species dominant for the remotely sensed vegetation class in which the sample points are located, and the sample points occupied by a non-dominant tree, was calculated as a map-accuracy measure. A similar measure for the map of 1972 was unfortunately not possible as no field data were available.

From the PCQM data relative density $\left(\mathrm{DE}_{\mathrm{r}}=[\right.$ number of individuals of species/total number of individuals] $\times$ $100)$, relative dominance $\left(\mathrm{DO}_{\mathrm{r}}=\right.$ [dominance of a species/dominance for all species] $\times 100$ ) and relative frequency $\left(F R_{r}=\right.$ [frequency of a species/sum of frequencies of all species] $\times 100$ ) were computed for the adult trees using the methods described by Cintrón \& Schaeffer Novelli (1984) in order to calculate the importance value (IV) of Curtis (1959) for each mangrove tree species. According to this method, relative dominance is based on tree diameter. Relative density and relative frequency were also calculated for young and juvenile mangrove trees. The IV for these vegetation layers was calculated as for the adult tree layers, but omitting relative dominance.

Statistical analyses. A G-test (Sokal \& Rohlf 1981) was performed on the absolute numbers of sample points located in a certain vegetation class or zone containing a certain mangrove species in order to detect differences in abundance between the adult and young vegetation layers at a particular location; this 
may reflect a static or spatially dynamic nature of regeneration. It was also used together with a $\chi^{2}$-test to test for significant seasonal differences in absolute juvenile densities. Seasonal differences in juvenile distribution are important when comparing their distribution patterns with that of adult or young trees, the distribution of which are not seasonally variable. Sampling in a single season may therefore give an erroneous idea of the dispersal potential of mangrove juveniles. Nevertheless, we emphasise a priori that seasonal differences between the wet and dry season recorded in this study may still have been subject to annual variability, which can only be determined by long-term, monthly sampling. Following the distribution of juveniles is important for understanding the ability of propagules to reach a certain area, and to reveal hazards such as propagule predation.

To investigate the similarity in distribution between the species in the different vegetation layers and to explore the links between vegetation and environmental factors (salinity, light intensity, propagule predator abundances), species ordinations (Kent \& Coker 1992) were performed on the adult, young and juvenile mangrove distributional data. It is important to emphasise that, contrary to classical statistical analyses (e.g. rank correlation tests), ordinations are the only way to effectively analyse large data matrices with information on samples versus species (or in this case species-layers), to cope with multiple absences (many matrix cells with zero values), and to indirectly or directly integrate environmental factors as explanatory factors (Dahdouh-Guebas et al. 2002a).

The samples-species input matrices were generated based on presence/absence data ( 0 or 1 ) and on abundance data ( 0 to 4 ) for each of the 99 sample points, whereby each sample in the matrix included the data from the 4 original PCQM quadrants. Using PC ORD for Windows (McCune \& Mefford 1997), detrended correspondence analysis (DCA) (Hill \& Gauch 1980) and canonical correspondence analysis (CCA) (Ter Braak 1986, 1994) were applied and the percentage of variance in the matrix that is explained by each axis was calculated. Although this combined ordination approach was suggested by Ter Braak (1995) to provide an added value with respect to the choice of environmental variables, the DCA and CCA essentially served different aims here. DCA was used to interpret the similarity in the distribution of age classes (adult, young and juvenile trees) within and among species. In contrast, CCA was used to test the hypothesis that a selection of environmental factors identified in earlier studies as playing a major role in or as determining the establishment of mangrove zonation patterns (based on univariate studies), are indeed responsible for the observed vegetation structure when analysed in a multivariate context, and to determine the extent of their role. The environmental variables and parameters used in the CCA were salinity (cf. Matthijs et al. 1999), light intensity (cf. Smith 1992), herbivorous crab abundance and snail abundance (cf. Dahdouh-Guebas et al. 1998). Monte-Carlo tests (randomisation tests) were used to test the significance of the eigenvalues and the species-environment correlations.

\section{RESULTS}

\section{Aerial photography and field surveys}

Fig. 4 shows the vegetation maps of 1972 and 1992 and shows that the total mangrove vegetation area decreased during this period (see also Table 1) without, however affecting the relative floristic composition. The unvegetated sandy area in the upper right of the vegetation map of 1972 (Fig. 4a) corresponds to bare sand and low beach vegetation that once formed a dense forest with the surrounding mangrove, as reported by the interviewees. In fact, locals marked this very area as the starting point for mangrove cutting in 1964 because it was the thinnest and most easily accessible area in the forest, and in addition could be used to spot incoming 'dhows' (traditional trade boats). Clusters of remaining mangrove stumps with clear signs of cutting in the field as well as the interviews revealed that in general Rhizophora mucronata, Ceriops tagal and Bruguiera gymnorrhiza are the preferred species for cutting. After 1972, the sandy area expanded at the expense of the mangrove stand (see Fig. 4b). This was still on-going in 1999, with visible effects to trees adjacent to the sandy area in the field between the surveys of 1997 and 1999, as evidenced

Table 1. Changes in areal extension (area in $\mathrm{m}^{2}$ ) between 1972 and 1992 for some land-cover classes and mangrove vegetation assemblages identified from aerial photographs. Georeferencing was based on 5 GPS points with an average accuracy of $10.5 \mathrm{~m}$. The increase in some of the mangrove vegetation assemblages was due to the existence of a large 'mixed' zone where no particular species dominated in 1972

\begin{tabular}{|lccc|}
\hline Assemblage/Class & 1972 & 1992 & Change (\%) \\
\hline Avicennia marina & 23310 & 9292 & -60.14 \\
Ceriops tagal & 4579 & 3118 & -31.91 \\
Rhizophora mucronata & 1897 & 2304 & +21.45 \\
Sonneratia alba & 0 & 2652 & +100.00 \\
Mixed mangrove & 15454 & 4613 & -70.15 \\
Total mangrove area & 45239 & 21978 & -51.42 \\
Cocos nucifera plantation & & & \\
$\quad$ adjacent to old fishermen's & & \\
place (Fig. 3) & 6377 & 915 & -85.65 \\
Unvegetated (sandy) & 2078 & 7057 & +239.61 \\
\hline
\end{tabular}


by the presence of entire (i.e. not cut) dead adult trees at the margins of the sandy stretch (Fig. 5a,b). The Sonneratia alba assemblage in the upper right corner of the 1992 vegetation map (Fig. 4b) is another remainder of the originally larger seaward mangrove belt. It is physically unable to stop the high-energy effects of waves, which penetrate the $S$. alba assemblage, fall onto the beach, and are eroding terrestrial coconut plantations (Fig. 5c).

During the ground-truth surveys, a difference was noted between the regular slope of the intertidal zone that exists in all seaward or creekward areas, and the multiple topographic ridges and depressions present in more landward zones. Roughly these 2 areas are separated by a series of sandy ridges running parallel to the creek (Fig. 4b). The Avicennia marina fringe on the landward side is reduced in area (Fig. 4; Table 1). However, within the mixed zone, individual A. marina trees present in 1972 (Fig. 4a) have formed a pure patch (see photograph and vegetation map of 1992: Figs. 3b \& 4b). Besides the seaward A. marina assemblage, within the remainder of the mangrove forest

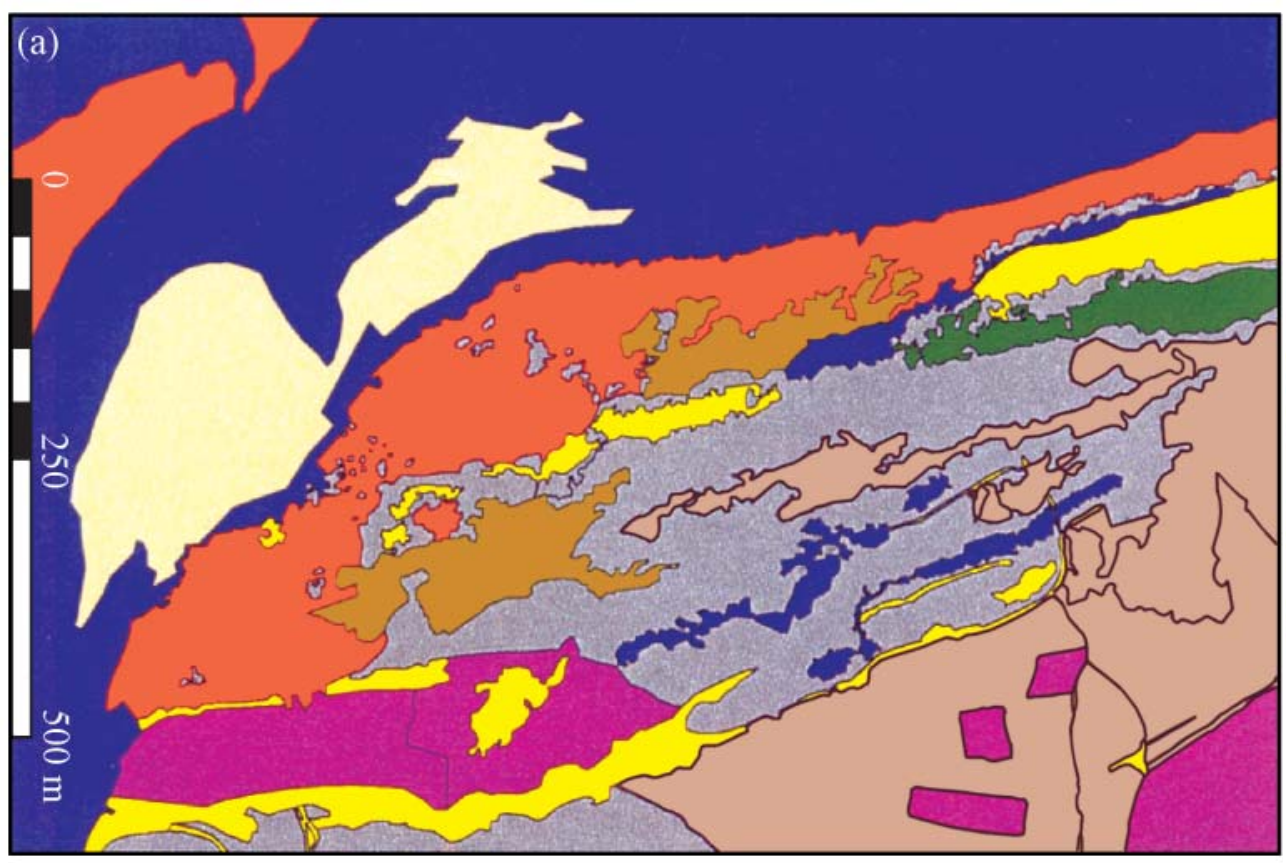

$Q 7$ degraded

\section{open character}

의 outside study area

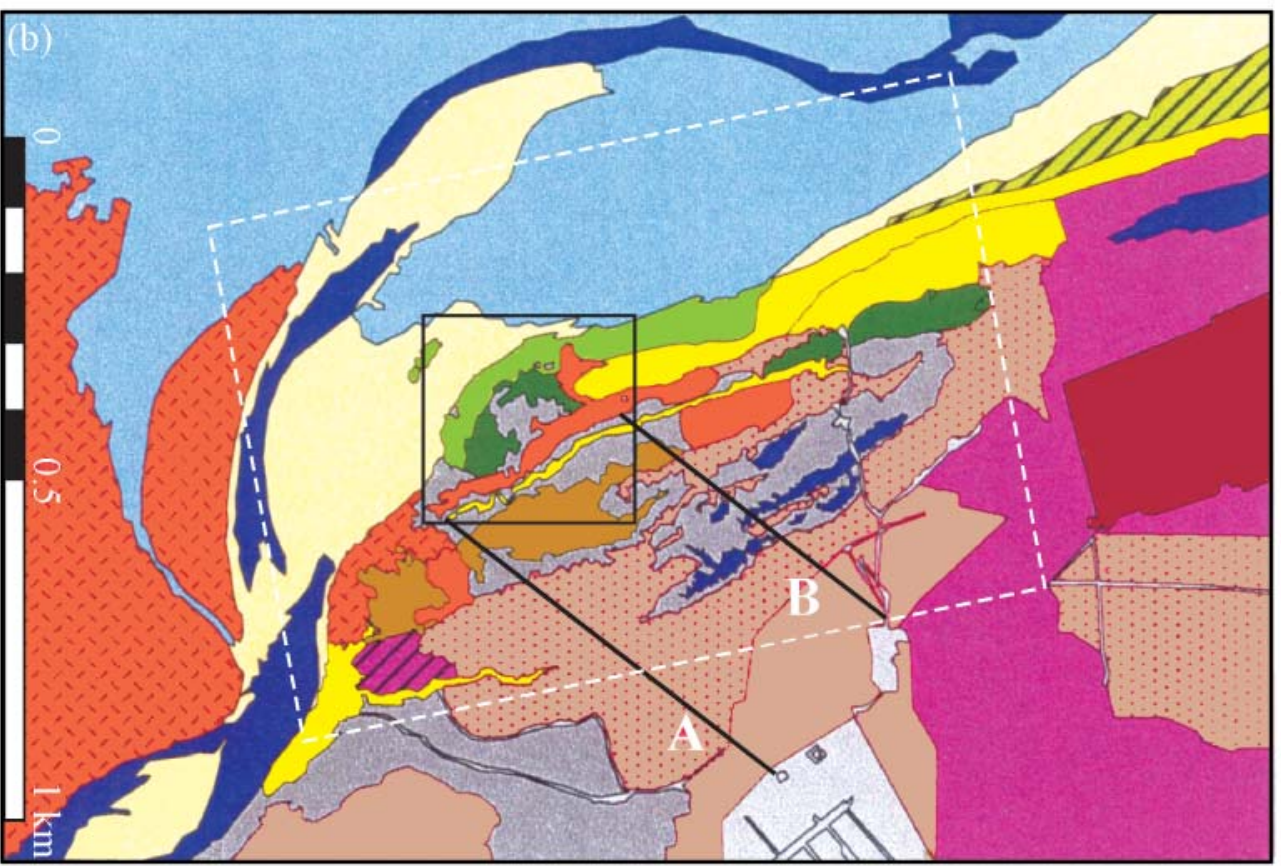

Fig. 4. Vegetation maps of study site in (a) 1972 and (b) 1992. Approximate orientation of photographs with respect to each other is indicated by dashed rectangle. Long black lines: Transects A and $\mathrm{B}$; black rectangle: locations of 5 transects shown in Fig. 6. As shown in the key above, a dotted pattern represents an area with an open character, a hatched pattern an area that is degraded and a pattern with small lines the area outside our study field, all of which are independent of the colour 

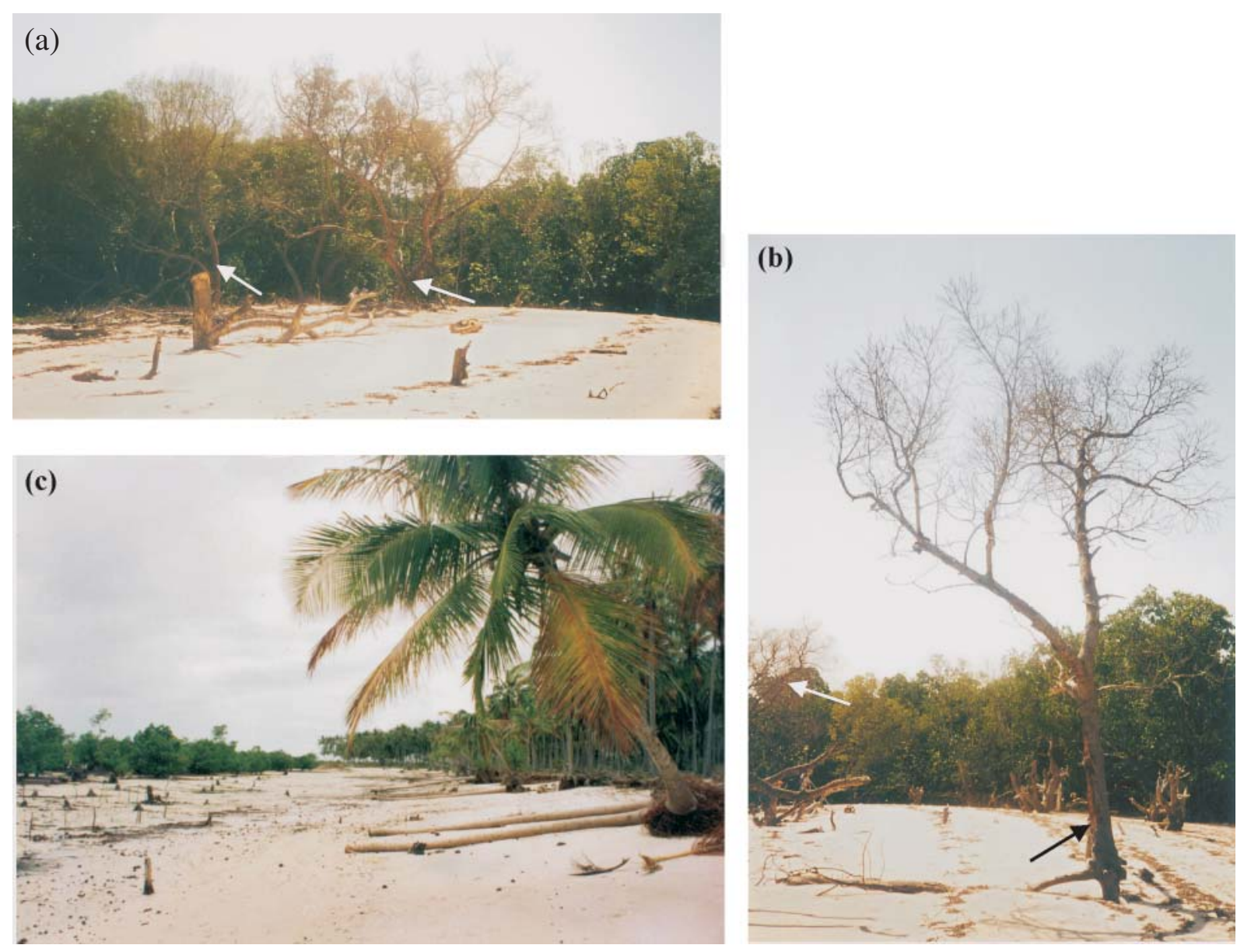

Fig. 5. (a) (b) Margins of expanding sandy area indicated by arrows in middle left of Fig. 3b; arrows indicate entire Rhizophora mucronata trees that died naturally; in the foreground and background are also stumps of the same trees chopped down by villagers. (c) Degraded Sonneratia alba assemblage at low tide (left) in 1992, and erosive effects on terrestrial coconut plantations (right) in location indicated by arrow on top right of Fig. 3b. Here, coconut trees are uprooted by wave action

the landward Ceriops tagal assemblage of 1972 seems to be the only other assemblage that is expanding (Fig. 4). However, since the seaward C. tagal assemblage of 1972 has disappeared, this is not reflected in the total surface covered by $C$. tagal (Table 1).

\section{Mangrove zonation - horizontal vegetation structure}

The forest section studied in the seaward transects, which gradually slopes down towards the creek, is (partially) zoned from land to sea with a landward Avicennia marina-dominated zone, an A. marina/Bruguiera gymnorrhiza/Ceriops tagal/Rhizophora mucronata mixed zone, a $R$. mucronata-dominated and/or seaward A. marina-dominated zone and finally a Sonneratia alba-dominated zone (Fig. 6). However, in the more landward areas, where topography is irregular with many small emergent areas even at spring high tide, zonation is less evident and species composition seems restricted initially to C. tagal, A. marina and Lumnitzera racemosa and more landwards to $A$. marina and $L$. racemosa as was evident from Transects A and B (not shown). In these areas other species are occasionally present, but $R$. mucronata, which is often found near regularly flooded, small creeklets (as small as $1 \mathrm{~m}$ wide), is almost totally absent. Within this landward area the border between the vegetation zone dominated by $R$. mucronata and that dominated by $C$. tagal corresponds with the high water limit of neap tide (F.D.G. pers. obs.).

Although Lumnitzera racemosa was occasionally observed along Transects A and B, these transects did not contain zones or patches other than those observed from the aerial photographs, and were therefore not shown. The most landward species was Avicennia marina, but some local inhabitants recall Rhizophora mucronata as the first mangrove tree species encoun- 


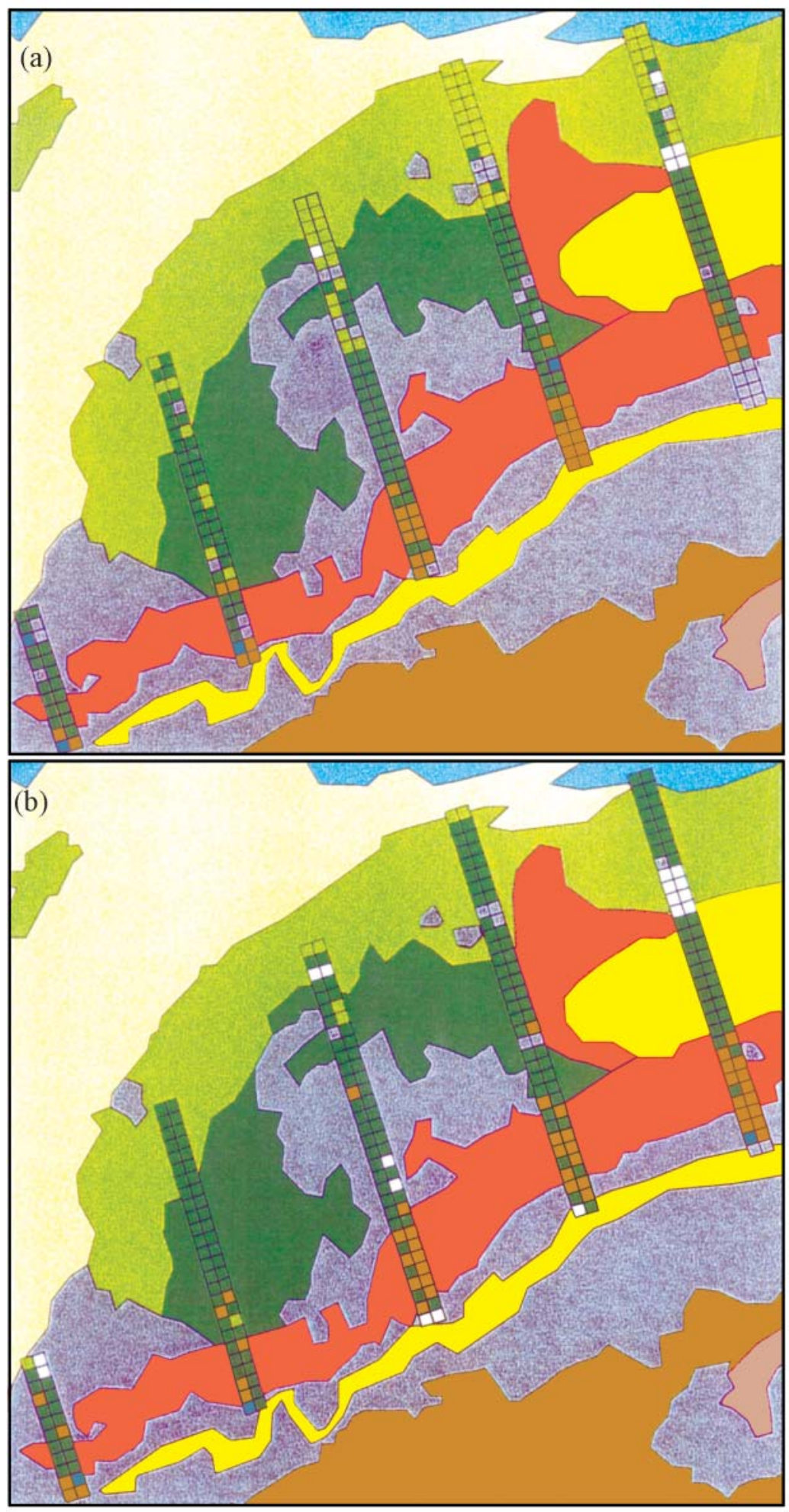

Fig. 6. Close-up of overlay of visualised point-centred quarter method (PCQM) data from 5 parallel transects on vegetation map of 1992 for (a) adult and (b) young mangrove trees. The sixth orthogonal (overlapping) transect is not shown. Each block of 4 squares represents 4 PCQM quadrants with the PCQM sample point in the centre; 1 block represents $5 \mathrm{~m} \times 5 \mathrm{~m}$. Each colour represents a different tree species, with the tree nearest to the sample point being considered dominant (for detailed PCQM description see Cintrón \& Schaeffer Novelli 1984)

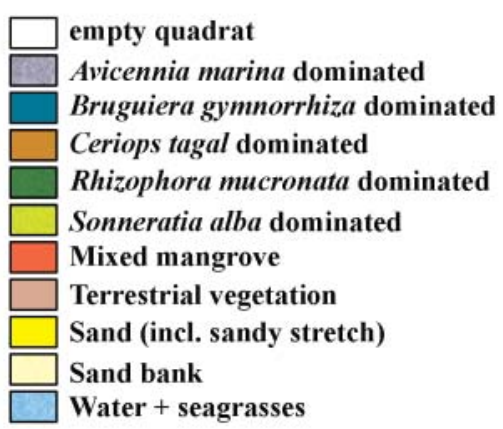

tered on the way from the village to the fishermen's new place (Fig. 3). Locals identified $R$. mucronata as the species preferred for house building, with $A$. marina being less sought after.

\section{Mangrove stratification-vertical vegetation structure}

The quantified PCQM vegetation data from the zoned forest section are given in Tables 2 \& 3 . It can be seen that Rhizophora mucronata is ubiquitously important species in all vegetation classes identified on the aerial photograph and in all vegetation layers (see Fig. 6a). In the landward assemblages ( $R$. mucronata, mixed mangrove) the understorey is well represented, particularly by Ceriops tagal, as can be seen in the overlay of young trees (Fig. 6b) and the distribution of juveniles (Fig. 7). The absolute densities of the juveniles differed significantly between the 2 seasons over the entire study site $\left(\chi^{2}=25.526\right.$; $\mathrm{df}=2$; $\mathrm{p}<0.001)$ and for the different forest patches, except for the Sonneratia alba zone $(G$-test $=4.194$; $\mathrm{df}=2$; not significant). We repeat that seasonal differences or correspondences may still have been subject to annual variability.

The results of the $G$-test (Table 4) show that the observed differences between the abundance of adult and young trees in each vegetation class were not significant, except for the most seaward zones (Avicennia marina and Sonneratia alba).

Outliers do not dominate the DCA ordination graph and species clusters are easily distinguishable (Fig. 7). Although it 


\begin{tabular}{|c|c|c|c|c|}
\hline 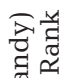 & $N \backsim \forall \neg m$ & $N m m \neg m$ & $N \forall m \neg \forall$ & $r A m N A$ \\
\hline$\underset{0}{0} \geq$ & S্ণ & 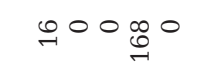 & గ్రం బ \& & ஜం 교 \\
\hline 营 & 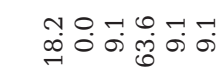 & 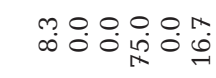 & 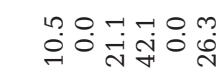 & 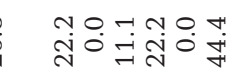 \\
\hline $\begin{array}{l}D_{0} \\
\geq 0 \\
0 \\
0\end{array}$ & 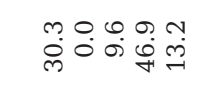 & & & \\
\hline 苋氙 & 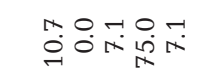 & ঋ๐유 & 文 O & 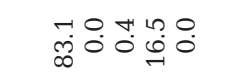 \\
\hline & & & & \\
\hline ฮี & सा कान & $m$ & $m+a+4$ & $\sqrt{4 m-\infty}$ \\
\hline$\underset{0}{\sharp} \geq$ & 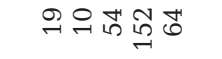 & 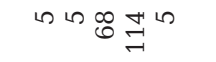 & 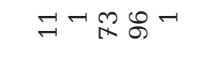 & 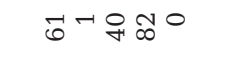 \\
\hline$\stackrel{0}{\substack{0 \\
d}}$ & 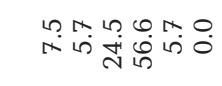 & ஸ் & 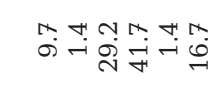 & 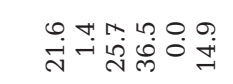 \\
\hline$\sum^{2}$ & 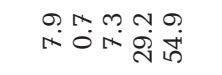 & & & \\
\hline 藏 & 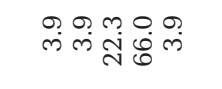 & 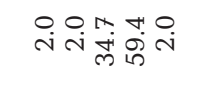 & $\begin{array}{l}90 \\
\dot{0} \\
\dot{0}\end{array}$ & 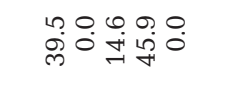 \\
\hline 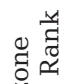 & $m \forall \forall N$ & $N \forall \forall \mapsto m$ & $m \backsim m \rightarrow N$ & $N \forall m ー n$ \\
\hline I & 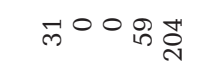 & $\underset{N}{ }$ & 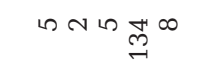 & $\stackrel{\infty}{\rightarrow}+\underset{్}{\underset{J}{H}}$ \\
\hline శี & 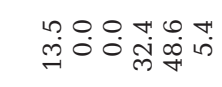 & 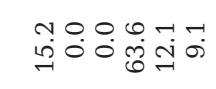 & 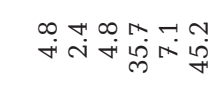 & 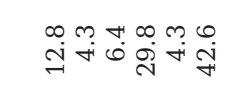 \\
\hline $\begin{array}{l}\widetilde{\Xi} \\
\text { ปี }\end{array}$ & 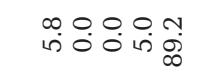 & & & \\
\hline ら藏 & 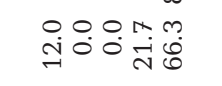 & 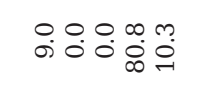 & 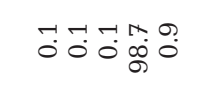 & 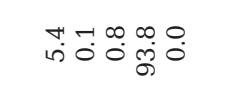 \\
\hline 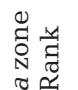 & $m \backsim \forall-N$ & $\forall \ln r \mathrm{~N}$ & $N \forall m \neg n$ & $N \forall m ー n$ \\
\hline ฐี & m̊ & $\stackrel{\circ}{\rightarrow} \stackrel{\sim}{\rightarrow} \underset{\sim}{-}$ & 요료 & $\underset{\forall}{\mathscr{N}} \mathrm{N} \underset{\exists}{\sim}$ \\
\hline 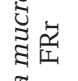 & 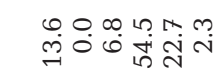 & అ̆ & 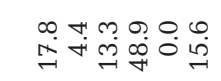 & 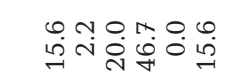 \\
\hline 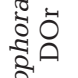 & 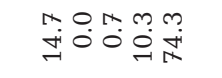 & & & \\
\hline 霆藏 & mọ m m & 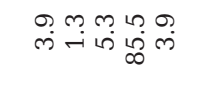 & 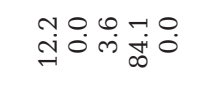 & 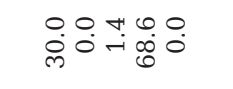 \\
\hline 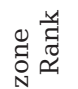 & N৫nー & HのNー & $m \backsim N \nleftarrow \nleftarrow$ & 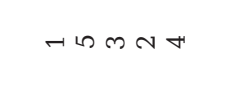 \\
\hline $\mathbb{Z} Z$ & 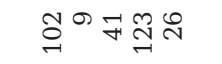 & $m \sigma \underset{+}{\infty} \underset{\sim}{\infty} m$ & m্ఛฺ & 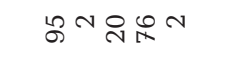 \\
\hline 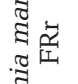 & 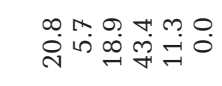 & 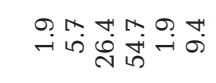 & 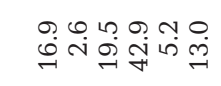 & 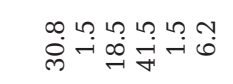 \\
\hline ปี & 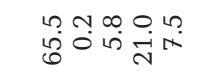 & & & \\
\hline 安藏 & 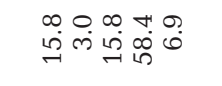 & 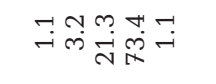 & 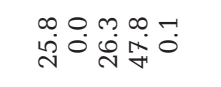 & تُ0 \\
\hline 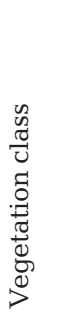 & 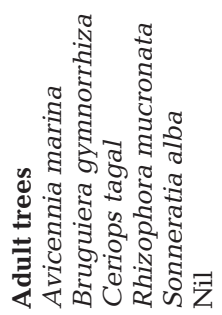 & 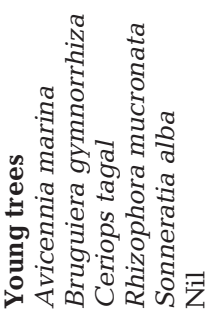 & 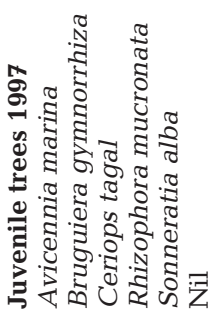 & 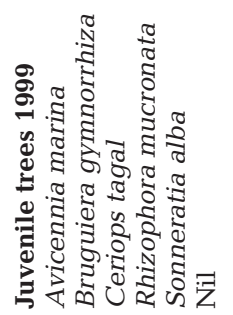 \\
\hline
\end{tabular}

was not the purpose of this ordination to confirm zonation, the latter can be deduced from Fig. 7, which shows a mixed cluster (Avicennia marina, Bruguiera gymnorrhiza, Ceriops tagal and Rhizophora mucronata), an $A$. marina-R. mucronata cluster and a Sonneratia alba cluster, corresponding to 'zones' from land to sea in the field survey. A. marina is distributed in a bimodal pattern, forming landward and the most seawards zone (seaward together with $S$. alba). This zonation pattern, together with the ability of $A$. marina to widely disperse its seeds, contributes to its central elongated position along the first axis in the ordination plot. The eigenvalues for the first and second axis are 0.404 and 0.194 respectively and the variance explained by the same axes are 44 and $8 \%$ respectively. The species clusters represented by $A$. marina, B. gymnorrhiza and $S$. alba have the widest spread along the first axis (>40 Units compared to approximately 20 Units for C. tagal and R. mucronata) and, particularly for these species clusters, the data points for adult and young individuals tend to lie closer together, whereas those for juveniles lie apart. This trend is less obvious for the other species. The variance does not change significantly when juvenile distributional data are omitted from the matrices.

\section{Relationships between vegetation structure and environment}

The environmental variables show little seasonal variability for salinity $(<1.25 \%$, Table 5), which was therefore averaged between seasons when entered in the multivariate analysis matrix. Light-intensity measurements in 1997 suffered under erratic weather conditions (clouds, rain) and were omitted from analysis. The 1999 light intensity measurements show an expected lower value for densely forested zones (Table 5). 
Table 3. Relative density (DEr), relative dominance (DOr), relative frequency (FRr) and importance value (IV) for landward and seaward A. marina fringe separately and for all vegetation classes together

\begin{tabular}{|c|c|c|c|c|c|c|c|c|c|c|c|c|c|c|c|}
\hline \multirow[t]{2}{*}{ Vegetation class } & \multicolumn{5}{|c|}{ Landward A. marina zone } & \multicolumn{5}{|c|}{ Seaward A. marina zone } & \multicolumn{5}{|c|}{ All classes } \\
\hline & DEr & DOr & $\mathrm{FRr}$ & IV & Rank & DEr & DOr & $\mathrm{FRr}$ & IV & Rank & DEr & DOr & $\mathrm{FRr}$ & IV & Rank \\
\hline \multicolumn{16}{|l|}{ Adult trees } \\
\hline Avicennia marina & 23.5 & 73.9 & 19.0 & 116 & 1 & 13.2 & 28.8 & 21.9 & 64 & 2 & 10.3 & 16.5 & 14.5 & 41 & 3 \\
\hline Bruguiera gymnorrhiza & 5.9 & 0.4 & 9.5 & 16 & 4 & 1.5 & 0.1 & 3.1 & 5 & 4 & 1.8 & 0.1 & 6.1 & 8 & 5 \\
\hline Ceriops tagal & 47.1 & 19.4 & 47.6 & 114 & 2 & 0.0 & 0.0 & 0.0 & 0 & 5 & 11.5 & 2.0 & 11.7 & 25 & 4 \\
\hline Rhizophora mucronata & 20.6 & 5.6 & 19.0 & 45 & 3 & 76.5 & 51.3 & 59.4 & 187 & 1 & 55.9 & 11.6 & 44.7 & 112 & 1 \\
\hline Sonneratia alba & 2.9 & 0.7 & 4.8 & 8 & 5 & 8.8 & 19.8 & 15.6 & 44 & 3 & 20.5 & 69.9 & 21.2 & 112 & 2 \\
\hline Nil & & & 0.0 & & & & & 0.0 & & & & & 1.7 & & \\
\hline \multicolumn{16}{|l|}{ Young trees } \\
\hline Avicennia marina & 0.0 & & 0.0 & 0 & 4 & 1.6 & & 3.3 & 5 & 3 & 4.0 & & 7.6 & 12 & 3 \\
\hline Bruguiera gymnorrhiza & 9.7 & & 13.0 & 23 & 3 & 0.0 & & 0.0 & 0 & 4 & 1.6 & & 4.7 & 6 & 5 \\
\hline Ceriops tagal & 51.6 & & 43.5 & 95 & 1 & 6.3 & & 13.3 & 20 & 2 & 15.7 & & 18.8 & 35 & 2 \\
\hline Rhizophora mucronata & 38.7 & & 34.8 & 73 & 2 & 92.1 & & 73.3 & 165 & 1 & 75.0 & & 55.3 & 130 & 1 \\
\hline Sonneratia alba & 0.0 & & 0.0 & 0 & 4 & 0.0 & & 0.0 & 0 & 4 & 3.7 & & 7.1 & 11 & 4 \\
\hline Nil & & & 8.7 & & & & & 10.0 & & & & & 6.5 & & \\
\hline \multicolumn{16}{|l|}{ Juvenile trees 1997} \\
\hline Avicennia marina & 43.0 & & 25.0 & 68 & 2 & 0.2 & & 7.1 & 7 & 4 & 68.3 & & 10.8 & 79 & 1 \\
\hline Bruguiera gymnorrhiza & 0.0 & & 0.0 & 0 & 4 & 0.1 & & 4.8 & 5 & 5 & 0.0 & & 2.7 & 3 & 5 \\
\hline Ceriops tagal & 44.7 & & 34.4 & 79 & 1 & 0.8 & & 9.5 & 10 & 2 & 7.5 & & 18.8 & 26 & 3 \\
\hline Rhizophora mucronata & 12.3 & & 37.5 & 50 & 3 & 98.7 & & 50.0 & 149 & 1 & 24.2 & & 39.9 & 64 & 2 \\
\hline Sonneratia alba & 0.0 & & 0.0 & 0 & 4 & 0.3 & & 9.5 & 10 & 3 & 0.0 & & 4.0 & 4 & 4 \\
\hline Nil & & & 3.1 & & & & & 19.0 & & & & & 23.8 & & \\
\hline \multicolumn{16}{|l|}{ Juvenile trees 1999} \\
\hline Avicennia marina & 87.5 & & 34.8 & 122 & 1 & 42.7 & & 26.2 & 69 & 2 & 64.6 & & 21.7 & 86 & 1 \\
\hline Bruguiera gymnorrhiza & 0.0 & & 0.0 & 0 & 4 & 0.0 & & 2.4 & 2 & 5 & 0.0 & & 2.4 & 2 & 4 \\
\hline Ceriops tagal & 5.4 & & 26.1 & 31 & 3 & 0.2 & & 14.3 & 14 & 3 & 2.4 & & 18.9 & 21 & 3 \\
\hline Rhizophora mucronata & 7.1 & & 30.4 & 38 & 2 & 57.1 & & 50.0 & 107 & 1 & 32.9 & & 36.3 & 69 & 2 \\
\hline Sonneratia alba & 0.0 & & 0.0 & 0 & 4 & 0.0 & & 2.4 & 2 & 4 & 0.0 & & 1.4 & 1 & 5 \\
\hline Nil & & & 8.7 & & & & & 4.8 & & & & & 19.3 & & \\
\hline
\end{tabular}

In the direct ordination (CCA) the environmental variables and parameters used failed to explain most of the observed variation in the vegetation data of the adult, young and juvenile mangroves. However, when the juvenile vegetation data are omitted from the matrices, the remaining adult and young distributional data clearly separate according to species, and to a certain extent according to environmental factors (Fig. 8). Adult and young Avicennia marina (AmAT and AmYT) and adult Sonneratia alba (SaAT) are weakly negatively correlated with the first axis, whereas young $S$. alba (SaYT) and Ceriops tagal (CtYT) are strongly positively correlated with it (Fig. 8). Adult and young Bruguiera gymnorrhiza (BgAT and BgYT) are strongly

Table 4. Results of G-test for differences in species proportions of adult tree and young tree individuals in each vegetation class. ns: not significant

\begin{tabular}{|lccc|}
\hline Vegetation zone & $G$ & $\mathrm{df}$ & $\mathrm{p}$ \\
\hline Avicennia marina & 30.363 & 5 & $<0.001$ \\
Rhizophora mucronata & 10.250 & 5 & $\mathrm{~ns}$ \\
Sonneratia alba & 66.830 & 3 & $<0.001$ \\
Mixed & 7.089 & 5 & $\mathrm{~ns}$ \\
Unvegetated (sand) & 6.822 & 4 & $\mathrm{~ns}$ \\
\hline
\end{tabular}

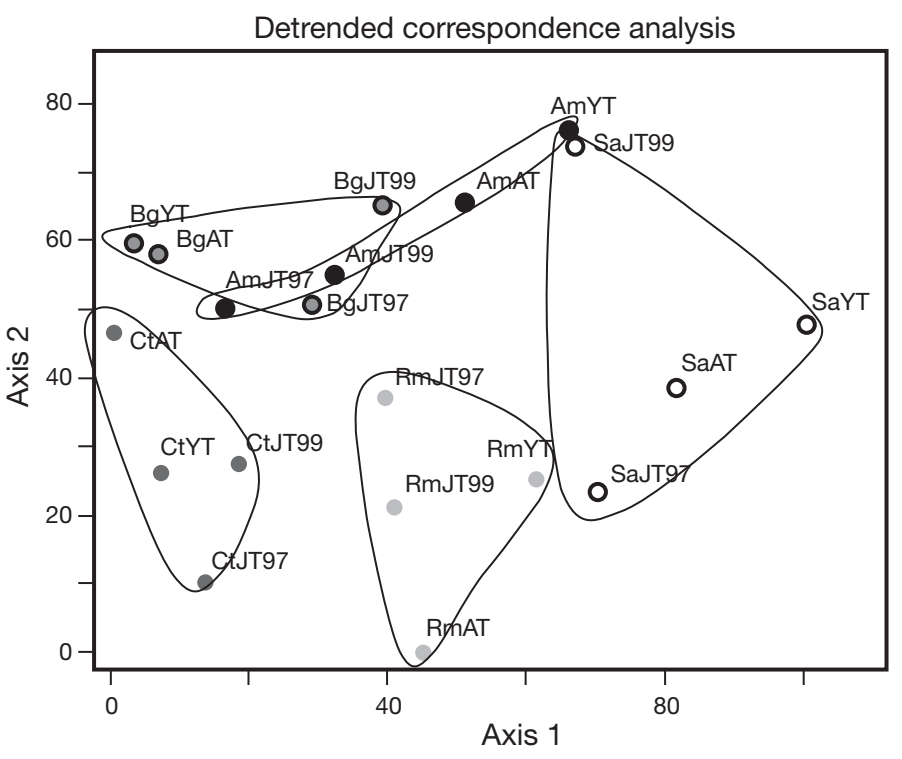

Fig. 7. Results of indirect species ordination (DCA) of presence/absence vegetation data for 99 sample points along 6 transects (each sample point consisted of 4 measurements, 1 in each quadrant) for adult (AT), young (YT) and juvenile (JT) trees recorded during field field study in 1997 (97) or in 1999 (99). Am: Avicennia marina; Bg: Bruguiera gymnorrhiza; Ct: Ceriops tagal; Rm: Rhizophora mucronata; Sa: Sonneratia alba 
Table 5. Mean $( \pm \mathrm{SD})$ for the environmental factors in each of the vegetation zones

\begin{tabular}{|c|c|c|c|c|c|}
\hline \multirow[t]{2}{*}{ Vegetation zone } & \multicolumn{2}{|c|}{$\longrightarrow$ Salinity } & \multirow{2}{*}{$\begin{array}{l}\text { Light } 1999 \\
\quad(\text { lux })\end{array}$} & \multicolumn{2}{|c|}{ Abundance } \\
\hline & 1997 & 1999 & & Crab (burrows $\mathrm{m}^{-2}$ ) & Snails (ind. $\mathrm{m}^{-2}$ ) \\
\hline Avicennia marina & $35.24 \pm 2.39$ & $34.11 \pm 2.26$ & 3480.00 & $5.00 \pm 4.17$ & $0.73 \pm 1.58$ \\
\hline Rhizophora mucronata & $34.29 \pm 1.86$ & $33.06 \pm 1.00$ & 5905.00 & $5.39 \pm 4.65$ & $1.83 \pm 2.64$ \\
\hline Sonneratia alba & $33.47 \pm 2.37$ & $33.00 \pm 0.85$ & 23440.00 & $3.17 \pm 4.36$ & $1.57 \pm 3.09$ \\
\hline Mixed & $35.38 \pm 3.30$ & $34.73 \pm 1.98$ & 5880.00 & $5.64 \pm 3.84$ & $4.52 \pm 5.14$ \\
\hline Sparsely vegetated (sandy area) & $34.00 \pm 1.87$ & $35.00 \pm 1.00$ & 38415.00 & $4.00 \pm 8.94$ & $0.20 \pm 0.45$ \\
\hline
\end{tabular}

positively correlated with the second axis (Fig. 8). The canonical coefficients are highest for snail abundance with respect to the first axis (0.639) and for light conditions with respect to the second axis $(-0.944)$. These canonical coefficients are conceptually similar to the usual regression coefficients and represent the unique contribution of individual variables as opposed to the simple correlation coefficient between a variable and an ordination axis. The correlation coefficients that correspond to the abovementioned canonical coefficients are 0.703 for snail abundance with respect to the first axis and -0.727 for light conditions with respect to the second axis. Monte Carlo tests showed that for the first axis the species-environment correlations were not significant $\left(\mathrm{p}_{\text {Monte Carlo test }}=0.101\right)$, whereas for the second axis they were $\left(p_{\text {Monte Carlo test }}=0.013\right)$. However, the total amount of variability in the species data that could potentially be 'explained' by the environmental factors in this direct ordination was only 4.2 and

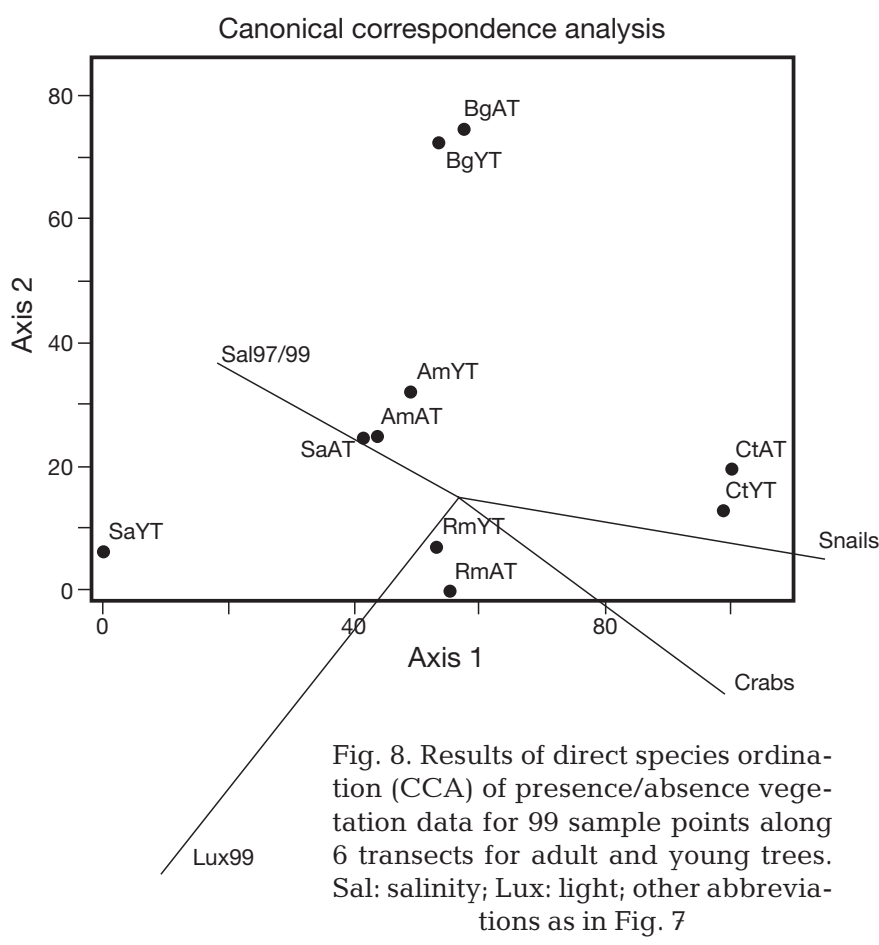

$2.8 \%$ for the first 2 axes respectively, which means that even though some differences are significant, other environmental factors contribute more to the observed vegetation structure.

\section{DISCUSSION AND CONCLUSIONS}

\section{Aerial photography and field surveys}

Analysis of aerial photographs revealed a decrease in mangrove area, and mangrove remains in the field, and interviews with local inhabitants indicated that human activity is the cause of the mangrove decline in Gazi, mainly overharvesting. This is in line with other literature indicating that Gazi is a site with a longstanding history of mangrove trade and human impact (e.g. Beeckman et al. 1989, Gallin et al. 1989, Vanhove et al. 1992, Kairo 1995a, Schrijvers et al. 1995, Fondo \& Martens 1998, Aloo 2000, Dahdouh-Guebas et al. 2000a, Hoorweg et al. 2000, Abuodha \& Kairo 2001, Kairo et al. 2001). The trees reported to be preferred for cutting were also listed in an in-depth survey of cutting preferences for mangrove species (Dahdouh-Guebas et al. 2000a). For Mida Creek, further north along the Kenyan coast, a similar anthropogenic cause for the quality and spontaneous regeneration of mangroves was reported (Kairo 2001). However, occasional natural hazards may further contribute to the reduction in mangrove area; the El-Niño rains of 1997 in Kenya for instance caused siltation and a subsequently massive die-off of adult and young trees within a small Rhizophora mucronata stand in Gazi Bay (J.G.K. pers. obs.). This $R$. mucronata stand, located in the upper right part of the vegetation map of 1992 (Fig. 4b), is however rejuvenating at present as a result of a rehabilitation programme (Kairo \& Dahdouh-Guebas in press).

Despite the deteriorating status of the forest adjacent to the village, and despite the general decrease in area, some mangrove assemblages have expanded. The low spatial dynamics of the sand banks in the creek over time (e.g. major sand banks of the creek in the aerial photographs of 1972 and 1992 are roughly on 
the same spot) has enabled Sonneratia alba to establish itself on these banks, very close to the $S$. alba zone of the adjacent forest (at about $150 \mathrm{~m}$ ). The low desirability of Avicennia marina for mangrove cutters, as in Mida Creek (Dahdouh-Guebas et al. 2000a), allowed this species to expand towards the seaward zone. The landward Ceriops tagal assemblage of 1972 has expanded into the mixed zone.

Unlike our previous report for a disturbed forest in Sri Lanka, using a similar remote sensing and groundtruth approach (Dahdouh-Guebas et al. 2000b), comparisons between the cover of adult or young mangrove trees and the dominant canopy species did not show a significant difference in Gazi Bay, except for the Avicennia marina and Sonneratia alba zone (Table 3). The predominantly seaward position of these zones in Kenya (the landward fraction of the disjunct A. marina zonation pattern is negligible in our study site: Fig. 4b) implies strong tidal currents that probably lead to the rare establishment of species compared to more landward zones. This is reflected in the high proportion of 'nil' (empty) data points for juveniles during both field surveys (Table 2), and in the absence of a significant seasonal difference between mangrove juveniles in the $S$. alba zone (regardless of season, the tidal currents remain strong in this most seaward zone). This rare establishment is also reflected by the low adult tree density in the $S$. alba zone (28.8 stems ha $^{-1}$ only) compared to the density in the Rhizophora mucronata zone (95.3 stems ha ${ }^{-1}$ ) and that in the mixed zone (205.2 stems ha ${ }^{-1}$ ). However, this is less evident for the seaward A. marina zone (156.5 stems ha ${ }^{-1}$ ) because of the $R$. mucronata-dominated understorey (1 ha $\left.=1000 \mathrm{~m}^{2}\right)$, the complex root system of which typically facilitates the trapping of propagules (pers. obs. by F.D.G. \& J.G.K.).

Since Rhizophora mucronata is a ubiquitously important species, irrespective of vegetation class or layer, it is emphasised that data from field surveys do not always correspond with remotely sensed data (see overgrowth of one species by another below). The opposite is also true, and fieldwork alone does not always give a complete picture. For instance, Beeckman et al. (1989) and Gallin et al. (1989) did not report the presence of Avicennia marina trees within the most seaward R. mucronata and Sonneratia alba-dominated zones in the same study area (see Fig. 4a for the past and Fig. 4a,b for the present situation). On the other hand, species distribution has been reported to be strikingly variable (Dahdouh-Guebas et al. 2002b). The discrepancy between remotely sensed and ground-truth data was reported earlier by Verheyden et al. (2002) for Sri Lankan mangroves and was attributed to the difficulties of detection within a stand due to interference of different image tonalities. However, in the case of Gazi Bay it is mainly due to canopy overgrowth of $R$. mucronata (with more stems recorded in the field study) by huge seaward A. marina (with few, thick stems and high canopies).

\section{Multivariate mangrove vegetation structure analysis}

The distribution of young individuals is more closely related to that of adult trees than to the distribution of juveniles, particularly for Avicennia marina, Bruguiera gymnorrhiza and Sonneratia alba (Fig. 7). The juveniles are thus generally spread over a wider area than adult trees, but young trees only survive near adult trees. This is as expected for A. marina and S. alba, which are pioneering species (e.g. Osborne \& Berjak 1997). The same observation was made for B. gymnorrhiza in Sri Lankan mangroves (Dahdouh-Guebas et al. 2000b). Although there was no difference rank for the importance of mangrove juveniles for the most common species, the 2 sampling years displayed a difference in numbers (Table 2), and further annual variability remains possible.

The clusters of adult, young and juvenile individuals of one species can easily be distinguished from those of other species (Fig. 7), meaning that the distributions of these individuals are rather similar within species, and that there is no high degree of species mixing (except perhaps for pioneer species). At least for the landward zones, this is corroborated by the lack of significant differences between the distribution of adult and young trees (Table 4 ).

The omission of juveniles from the ordination matrices emphasised the separation between species clusters (Fig. 8). Sonneratia alba and Avicennia marina adult trees clearly overlap in distribution, whereas this is less obvious for the young trees; young A. marina trees can be found all along the landward side, but $S$. alba young trees are restricted to the $S$. alba vegetation zone. An interesting observation on the understorey of the landward assemblages is that it may be wellrepresented in some mangrove assemblages (e.g. Ceriops tagal). This is contrary to the general claim that an understorey, whether composed of mangrove or of non-mangrove species, is absent from mangrove stands (Janzen 1985, Snedaker \& Lahmann 1988). In fact, it is the very presence of $C$. tagal in the understorey of assemblages dominated by other mangroves that may camouflage a dynamic shift (e.g. Kairo et al. 2002), either imminent or incipient. In the light of succession, the present study seems to support the hypothesis that mangrove stands should not be considered as intermediate communities preceding terrestrial forests (Johnstone 1983), at least not for high tidal amplitude areas such as Gazi Bay. Whether the results 
of this study favour the hypothesis that mangrove forest comprises a community with its own successional stages (leading to zonation) and with its own climax (Snedaker 1982, Johnstone 1983) is not clear; primarily because of the anthropogenic impact in Gazi Bay, which has been too intensive to speculate on natural succession sensu stricto.

An overall striking facet of the CCA ordination analysis is the extremely low explanatory power of environmental variables claimed to play a major role in the shaping of mangrove vegetation structure, as concluded from univariate studies. This emphasises that mangrove zonation is the result of a complex interaction and synergism between spatial and temporal factors that extend beyond those investigated in this paper.

\section{Predictions based on vegetation history}

In Gazi Bay, anthropogenic influences (e.g. cutting) have first led to a direct loss of mangroves (e.g. Beeckman et al. 1989, Gallin et al. 1989, Vanhove et al. 1992, Kairo 1995a, Schrijvers et al. 1995, Fondo \& Martens 1998, Aloo 2000, Dahdouh-Guebas et al. 2000a, Hoorweg et al. 2000, Abuodha \& Kairo 2001, Kairo et al. 2001, this study), and second to further natural degradation (expanding sandy area). Yet, because this site is subject to a pronounced tidal regime, zonation seems to be imposed, in contrast for instance to disturbed sites in Sri Lanka where tidal influence is almost absent (Dahdouh-Guebas et al. 2000b).

The similar distribution of adult and younger vegetation layers (Table 4 ; Fig. 7), leads us to predict that under a 'no-impact scenario' (i.e. in the absence of further human impact or natural catastrophes), in an approximately 10-20 yr period (roughly the same period in the future as that analysed herein), no major spontaneous dynamic shifts in the natural distribution of the species are to be expected in Gazi Bay, except for a possible further expansion of the sandy area due to synergism between the former selective cutting of trees (primarily Rhizophora mucronata) and the subsequent intrusion of sand into the mangroves (Fig. 5a,b). Even when the incidence of mangrove cutting is lower, siltation is able to kill these trees, as evidenced by the presence of dead standing trees in the sandy area (see 'Results'). This may lead to the disappearance of the $R$. mucronata zone, which may be replaced by Avicennia marina, a minor shift considering that these 2 species currently form adjacent assemblages and are also present as individuals in each other's zones. A. marina can cope with more arid conditions (e.g. dry soils) and high light intensity (low forest cover), environmental conditions that are present on the sandy area and that are comparable to those in the landward A. marina zone. Although A. marina is known to thrive in a disjunct zone, it must be determined to which extent trees in the seaward zone, with a different morphology than specimens in the landward zone (Dahdouh-Guebas et al. in press), are able to withstand conditions of the landward zone.

A 'mangrove cutting scenario' following the current cutting preferences is likely to follow the same trend as the 'no impact scenario', but is expected to speed up the expansion of the sandy area, and the degradation of Rhizophora mucronata. Besides the replacement of the $R$. mucronata zone by Avicennia marina, another problem is the inadequacy of the frontal A. marina and Sonneratia zone to stop the effects of waves (Fig. 5c), and the slow washing away of the sand.

Under the above scenarios the landward mangroves on the vegetation map of 1992 (Fig. 4) are not likely to change substantially. Scenarios with greater impact, however, such as the future alteration or disappearance of the small topographic differences on the landward side at Gazi, will lead to a major reorganisation of the mangrove vegetation structure, as well as of the terrestrial vegetation in that area. Transformation of the multiple topographic ridges and depressions to a regular slope in this more landward mangrove would be expected to lead to an enlargement of the mangrove assemblages and landward species shifts or species extensions. Terrestrial assemblages on the ridges would be expected to disappear in favour of mangroves tolerant of high salinities, such as Avicennia marina and Lumnitzera racemosa. From the species-environment correlations (CCA) it is unclear to which environmental variable the distribution of Rhizophora mucronata is most correlated. However, as observed in the field (see 'Results'), the border between $R$. mucronata and Ceriops tagal assemblages may be linked to the high water limit at neap tide, and consequently to the amount of time the vegetation is submerged daily. Such regularly flooded areas, e.g. newly formed creeklets, would be expected to become fringed with $R$. mucronata and $C$. tagal. This prediction is valid provided there are no regenerative constraints such as propagule predation. From the CCA (Fig. 8), it can be seen that $C$. tagal positively correlates with propagule predator density, which is in line with earlier reports regarding propagule predation (DahdouhGuebas et al. 1997, 1998), and may also explain the shift from a mixed mangrove area in 1972 to a C. tagal area in 1992 (see Kairo et al. 2002).

Independent of the scenario, human interference may be needed to prevent the sandy area from expanding. It might be preferable to replant large, but protected, areas with the more vulnerable mangrove species such as Rhizophora mucronata. Small-scale 
reforestation programmes in Gazi Bay (Kairo 1995a,b) have been shown to successfully (re)convert denuded or degraded mangrove areas into functional forest units (Bosire et al. 2003, 2004). This implies that both floral secondary succession and faunal recruitment occur within the regeneration plots. Continuous monitoring of past and present mangrove vegetation, in natural forests as well as rehabilitation areas, will enable us to better understand mangrove dynamics and perhaps predict the future vegetation structure in more detail. An in-depth study of the introgression between natural and artificially planted mangroves will be be a new research challenge.

Acknowledgements. The first author is a Postdoctoral Researcher from the Fund for Scientific Research (FWO, Vlaanderen). The research was also financed with a specialisation fellowship of the Institute for the Promotion of Innovation by Science and Technology in Flanders (IWT), and by the European Commission (Contract No. IC18-CT96-0065), and is published with the support of the University Foundation of Belgium. We thank the staff of the Kenya Belgium Project and the Kenya Marine and Fisheries Research Institute (KMFRI) for providing logistic support. Much gratitude is due to all the inhabitants of Gazi, in particular Latifa Salim and family S. Ba'alawy for hosting us, Abdulhakim Abubakr Ali Jilo and Fatuma M. Saidi for their practical help in the field, and Abdulbasit M. Daghar, Fatuma M. Saidi, Samir Abubakr and Omari Juma Kisasi for their translation assistance during the interview surveys. Chris Gordon (Centre for African Wetlands, University of Ghana) is gratefully acknowledged for scientific and style comments on the paper. We also thank 3 referees for their constructive comments.

\section{LITERATURE CITED}

Abuodha PAW, Kairo JG (2001) Human-induced stresses on mangrove swamps along the Kenyan coast. In: Harper D, Boar R, Everard M, Hickley P (eds) Science and the sustainable management of shallow tropical waters. Hydrobiologia 458:255-265

Aloo P (2000) Marine resources. In: Hoorweg J, Foeken D, Obudho RA (eds) Kenya coast handbook. Culture, resources and development in the East African littoral. LIT Verlag, Münster, p 43-60

Beeckman H, Gallin E, Coppejans E (1989) Indirect gradient analysis of the mangal formation of Gazi Bay (Kenya). Silva Gandavensis 54:57-72

Bosire J, Dahdouh-Guebas F, Kairo JG, Koedam N (2003) Colonisation of non-planted mangrove species into restored mangrove stands in Gazi Bay, Kenya. Aquat Bot 76:267-279

Bosire J, Dahdouh-Guebas F, Kairo JG, Cannicci S, Koedam N (2004) Spatial variations in macrobenthic fauna recolonisation in a tropical mangrove bay. Biodiv Conserv 13:1059-1074

Brokaw N, Thompson J (2000) The H for DBH. For Ecol Manag 129:89-91

Cintrón G, Schaeffer Novelli Y (1984) Methods for studying mangrove structure. In: Snedaker SC, Snedaker JG (eds) The mangrove ecosystem: research methods. UNESCO, Paris, France, p 91-113
Cormier-Salem MC (1999) The mangrove: an area to be cleared... for social scientists. Hydrobiologia 413:135-142

Cottam G, Curtis JT (1956) The use of distance measures in phytosociological sampling. Ecology 37:451-460

Curtis JT (1959) The vegetation of Wisconsin. An ordination of plant communities. University of Wisconsin Press, Madison

Dahdouh-Guebas F (2002) The use of remote sensing and GIS in the sustainable management of tropical coastal ecosystems. Environ Dev Sustainability 4:93-112

Dahdouh-Guebas F, Verneirt M, Tack JF, Koedam N (1997) Food preferences of Neosarmatium meinerti the Man (Decapoda: Sesarminae) and its possible effect on the regeneration of mangroves. Hydrobiologia 347:83-89

Dahdouh-Guebas F, Verneirt M, Tack JF, Van Speybroeck D, Koedam N (1998) Propagule predators in Kenyan mangroves and their possible effect on regeneration. Mar Freshw Res 49:345-350

Dahdouh-Guebas F, Mathenge C, Kairo JG, Koedam N (2000a) Utilization of mangrove wood products around Mida Creek (Kenya) amongst subsistence and commercial users. Econ Bot 54:513-527

Dahdouh-Guebas F, Verheyden A, De Genst W, Hettiarachchi S, Koedam N (2000b) Four decade vegetation dynamics in Sri Lankan mangroves as detected from sequential aerial photography: a case study in Galle. Bull Mar Sci 67:741-759

Dahdouh-Guebas F, Verheyden A, Jayatissa LP, Koedam N (2001) A note on the identification of mangroves from aerial photography in Kenya and Sri Lanka. In: DahdouhGuebas F (ed) Mangrove vegetation structure dynamics and regeneration, $\mathrm{PhD}$ thesis, Vrije Universiteit Brussel, Brussels, p 73-83

Dahdouh-Guebas F, Kairo JG, Jayatissa LP, Cannicci S Koedam N (2002a) An ordination study to view vegetation structure dynamics in disturbed and undisturbed mangrove forests in Kenya and Sri Lanka. Plant Ecol 161: 123-135

Dahdouh-Guebas F, Verneirt M, Cannicci S, Kairo JG, Tack JF, Koedam N (2002b) An exploratory study on grapsid crab zonation in Kenyan mangroves. Wetlands Ecol Manag 10:179-187

Dahdouh-Guebas F, De Bondt R, Abeysinghe PD, Kairo JG, Triest L, Koedam N (in press) Comparative study of the disjunct zonation pattern of the grey mangrove Avicennia marina (Forsk.) Vierh. in Gazi Bay (Kenya). Bull Mar Sci

Duke NC (1991) A systematic revision of the mangrove genus Avicennia (Avicenniaceae) in Australasia. Aust Syst Bot $4: 299-324$

Duke NC, Jackes BR (1987) A systematic revision of the mangrove genus Sonneratia (Sonneratiaceae) in Australasia. Blumea 32: 277-302

Farnsworth EJ, Ellison AM (1997) The global conservation status of mangroves. Ambio 26:328-334

Fondo EN, Martens EE (1998) Effect of mangrove deforestation on macrofaunal densities, Gazi Bay, Kenya. Mangroves Salt Marshes 2:75-83

Gallin E, Coppejans E, Beeckman H (1989) The mangrove vegetation of Gazi bay (Kenya). Bull Soc R Bot Belg 122: 197-207

Hill MO, Gauch HG (1980) Detrended correspondence analysis: an improved ordination technique. Vegetatio 42:47-58

Hoorweg J, Foeken D, Obudho RA (eds) (2000) Kenya coast handbook. Culture, resources and development in the East African littoral, LIT Verlag, Münster

Janzen DH (1985) Mangroves: where's the understory? J Trop Ecol 1:89-92 
Jeathold R, Smidt H (1976) Farm management handbook of Kenya, Volume II. Part C, Ministery of Agriculture, Nairobi

Johnstone IM (1983) Succession in zoned mangrove communities: where is the climax? In: Teas HJ (ed) Tasks for vegetation science 8 . W. Junk, The Hague, p 131-139

Kairo JG (1995a) Artificial regeneration and sustainable yield management of mangrove forests in Gazi Bay, Kenya, MSc thesis botany, University of Nairobi, Nairobi

Kairo JG (1995b) Community participatory forestry for rehabilitation of deforested mangrove areas of Gazi Bay (Kenya). A first approach. Final technical report. University of Nairobi, Department of Botany, Nairobi

Kairo JG (2001) Ecology and restoration of mangrove systems in Kenya, PhD dissertation, Vrije Universiteit Brussel, Brussels

Kairo JG, Dahdouh-Guebas F (in press) Mangroves of Kenya. In: Ashton E (ed) Code of conduct for sustainable management of mangrove ecosystems. Internation Society of Mangrove Ecosystems (ISME), Okinawa, Japan

Kairo JG, Dahdouh-Guebas F, Bosire J, Koedam N (2001) Restoration and management of mangrove systems-a lesson for and from the East African region. S Afr J Bot 67: 383-389

Kairo JG, Dahdouh-Guebas F, Gwada PO, Ochieng C, Koedam N (2002) Regeneration status of mangrove forests in Mida Creek, Kenya: a compromised or secured future? Ambio 31:562-568

Kent M, Coker P (1992) Vegetation description and analysis. A practical approach, John Wiley \& Sons, Chichester

Lieth H, Berlekamp J, Fuest S, Riediger S (1999) Climate diagram world atlas, Backhuys, Leiden

Matthijs S, Tack J, Van Speybroeck D, Koedam N (1999) Mangrove species zonation and soil redox state, sulphide concentration and salinity in Gazi Bay (Kenya), a preliminary study. Mangroves Salt Marshes 3:243-249

McCune B, Mefford MJ (1997) Multivariate analysis of ecological data, Version 3.09, MjM Software, Gleneden Beach, OR

Osborne DJ, Berjak P (1997) The making of mangroves: the

Editorial responsibility: Victor de Jonge (Contributing Editor), Haren, The Netherlands remarkable pioneering role played by seeds of Avicennia marina. Endeavour 21:143-147

Schrijvers J, Van Gansbeke D, Vincx M (1995) Macrobenthic infauna of mangroves and surrounding beaches at Gazi Bay, Kenya. Hydrobiologia 306:53-66

Smith TJ (1987) Seed predation in relation to tree dominance and distribution in mangrove forest. Ecology 68:266-273

Smith TJ III (1992) Forest structure. In: Robertson AI, Alongi DM (eds) Tropical mangrove ecosystems. American Geophysical Union Washington, DC, p 101-136

Snedaker SC (1982) Mangrove species zonation: why? In: Sen DN, Rajpurohit KS (eds) Tasks for vegetation science 2, W. Junk, The Hague, p 111-125

Snedaker SC, Lahmann EJ (1988) Mangrove understorey absence: a consequence of evolution? J Trop Ecol 4:311-314

Sokal RR, Rohlf FJ (1981) Biometry. The principles and practice of statistics in biological research, 2nd edn. WH Freeman \& Co, New York

Ter Braak CJF (1986) Canonical correspondence analysis: a new eigenvector technique for multivariate direct gradient analysis. Ecology 67:1167-1179

Ter Braak CJF (1994) Canonical community ordination. Part I: Basic theory and linear methods. Ecoscience 1:127-140

Ter Braak CJF (1995) Ordination. In: Jongman RHG, Ter Braak CJF, Van Tongeren OFR. Data analysis in community and landscape ecology, Cambridge University Press, Cambridge, p 91-173

Tomlinson CB (1986) The botany of mangroves. Cambridge tropical biology series, Cambridge University Press, New York

Vandeput S (1999) De haalbaarheid van een kleinschalig ecotoeristisch project in Gazi. MSc thesis human ecology, Vrije Universiteit Brussel, Brussel (in Dutch)

Vanhove S, Vincx M, Van Gansbeke D, Gijselinck W, Schram D (1992) The meiobenthos of five mangrove vegetation types in Gazi Bay, Kenya. Hydrobiologia 247:99-108

Verheyden A, Dahdouh-Guebas F, De Genst W, Hettiarachchi S, Koedam N (2002) High-resolution vegetation data for mangrove research as obtained from aerial photography. Envion Dev Sustainability 4:113-133

Submitted: November 28, 2002; Accepted: December 1, 2003 Proofs received from author(s): April 22, 2004 